Egyptian Journal of Aquatic Biology \& Fisheries

Zoology Department, Faculty of Science,

Ain Shams University, Cairo, Egypt.

ISSN $1110-6131$

Vol. 25(2): $551-560$ (2021)

www.ejabf.journals.ekb.eg

\title{
Length-Weight Relationship and Fulton's Condition Factor of Macrobrachium nipponense (De Haan, 1849) in Siah Darvishan River, Iran
}

\author{
Mehrnoush Aminisarteshnizi \\ Department of Research Administration and Development, University of Limpopo, Republic of \\ South Africa \\ Email: Mehrnush.amini@gmail.com
}

\begin{abstract}
ARTICLE INFO
Article History:

Received: Dec. 13, 2020

Accepted: Jan. 21, 2021

Online: April 22

Keywords:

Relationship (LWR),

Condition factor,

Macrobrachium

nipponense,

Siah Darvishan river

\section{ABSTRACT}

The length-weight relationship (LWR) and condition factors (CF) of 1200 of the oriental river prawn Macrobrachium nipponense, collected from Siah Darvishan river from January to December 2015 were s t u died. The total length and body weight of M. nipponense ranged from $1.23-9.3 \mathrm{~cm}$ and $0.1-11.7 \mathrm{~g}$, respectively. A strong positive relationship was observed between the prawn length and weight $(r=$ 0.96). There were significant differences in the condition factors of males and females $(\mathrm{P}<0.05)$. The lowest $\mathrm{CF}$ value was observed in April $(\mathrm{CF}=0.81 \pm 0.04)$, while the highest was recorded in August $(\mathrm{CF}=1.30$ \pm 0.34). The sex ratio of 1.0 male: 1.98 female was observed, which deviated significantly from the theoretical one male: one female ratio, indicating that males were significantly more than females $(P<0.05)$. In this study, the regression coefficient (b) was more than 3.0, a value that indicates a positive allometry.
\end{abstract}

\section{INTRODUCTION}

The oriental river prawn (Macrobrachium nipponense) is natively distributed in China, Japan, Korea, Vietnam, Myanmar, and Taiwan, while in Iran, Uzbekistan and Iraq it is introduced (New et al., 2010). The same species were reported in the Anzali Lagoon in 2006 (De Grave \& Ghane, 2006). It belongs to the phylum of Arthropoda (Order: Decapoda; Family: Palaemonida (De Haan, 1849), and known to be omnivorous (New et al., 2010). Spawning occurs in spring and summer when males appear with a hard shell and females with a soft one mate (Wakefield, 2015). The temperature has an important influence on reproduction. Morphologically, there are differences between males and females. Mature males are larger than females (Bacheler, 2013). M.nipponense was first observed in Anzali Lagoon in 2006, and later on spread in northern Iran's water basins (Coad, 2016). Prawn and shrimp of the genus Macrobrachium and Penaeus are highly appreciated in the whole world. Because of 
their high protein value, they are used as condiments in food preparation (Cruz, 2013; Major, 2016).

Studies of fish biology are essential for the sustainable management and conservation of fish biodiversity. Moreover, understanding length-weight relationships in an aquatic organism, specifically fish, is crucial to fishery management (Khanipour et al., 2020). Notably, it is beneficial in assessing the average weight of a given length and the population's condition (Abowei et al., 2008). The condition factor of fish has also been widely used as an index of their growth and feeding intensity. The value of this index decreases with the increase in length, a relation that has affects the reproductive cycle of the fish. In addition, the condition factor reflects the effects of seasonal and habitat differences in the robustness of the species (Abowei, 2010). Hence, the current study was presented to evaluate the condition factor and length-weight relationship (LWR) of M.nipponense in Iran's Siah Darvishan river.

\section{MATERIALS AND METHODS}

\section{Study area}

Specimens of M.nipponense were collected from the Siah Darvishan river (GPS coordinates: $37^{\circ} 25^{\prime} 026.42^{\prime \prime} \mathrm{N}$ and $49^{\circ} 27^{\prime} 307.12^{\prime \prime} \mathrm{E}$ ) (Figure 1), which is a preferred habitat for the species. Ten (10) traps were randomly selected for sampling the prawn. All the traps were used simultaneously for the sampling of prawns in this study. The traps were checked every 24 hours, and the samples were collected at night for ten (10) nights per month, for twelve months (from January to December 2015).

\section{Specimen sampling}

All collected samples were immediately placed in iceboxes, and transported to the fish biology laboratory for further analyses. Samples were sorted into male and female. Total length (the distance from the rostrum tip to the end of telson) was measured for each sample with a Vernier caliper to the nearest $0.1 \mathrm{~mm}$. The prawns were then weighed with a balance to the nearest $0.1 \mathrm{~g}$. Samples taken in each month were measured and preserved separately. 


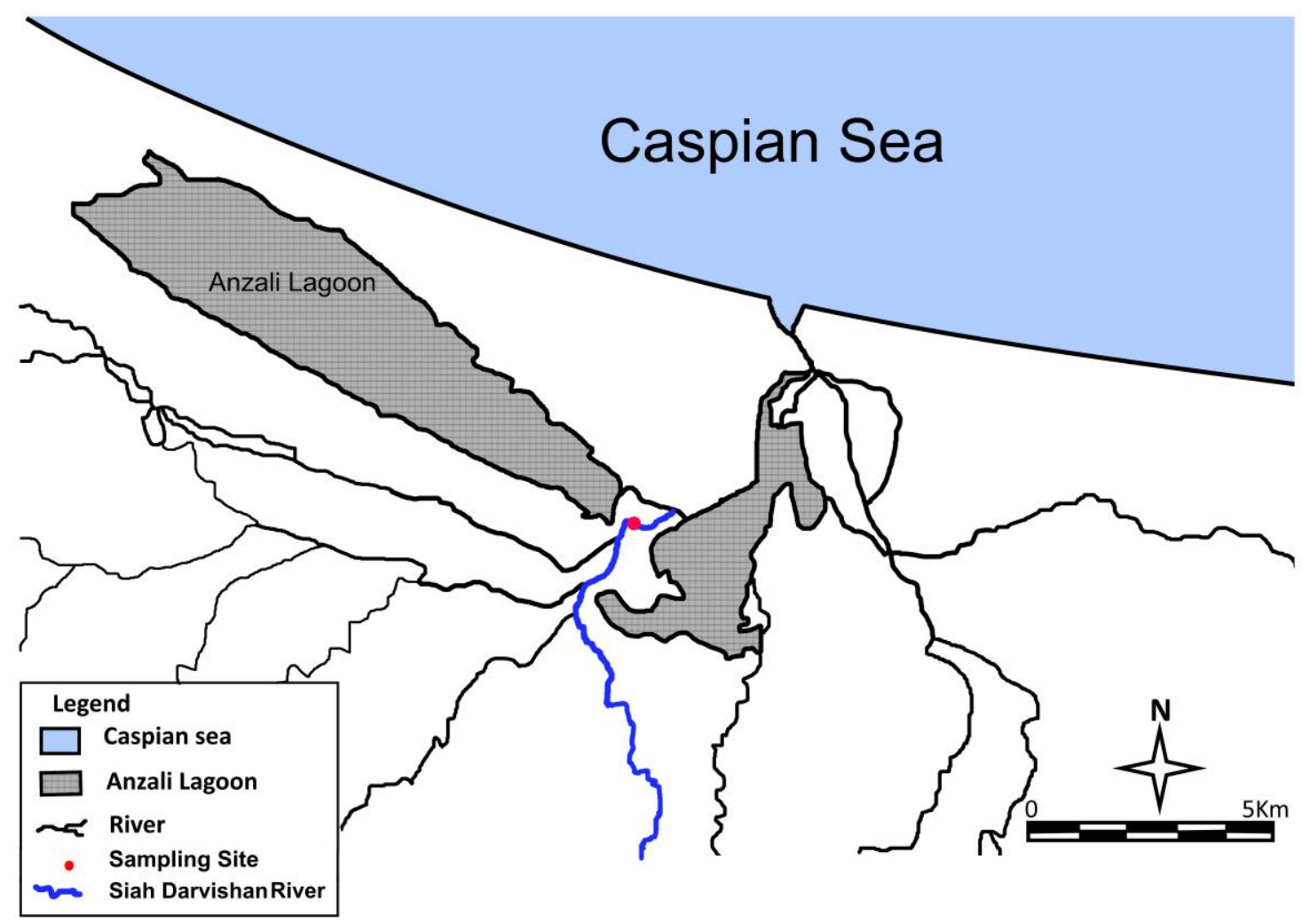

Figure 1. Location of the study area. The red circle is the sampling site

\section{Growth Pattern (Length and Weight)}

The recorded length (total length) of the individuals of the assessed prawn species was used. In all, a total of one thousand and two hundred (1200) specimens of M.nipponense was examined for the present study.

The length-weight relationship of prawns was estimated using linear regression (Pauly, 1983), according to the following equation:

$\mathbf{W}=\mathbf{a} \mathbf{L}^{\mathbf{b}}$

where, $\mathrm{W}=$ Weight $(\mathrm{g}), \mathrm{L}=$ Total Length $(\mathrm{cm}) \mathrm{a}=$ Intercept (Regression constant); $\mathrm{b}=$ Slope (Regression coefficient) (Pauly, 1983; Sparre et al., 1989).

\section{Condition Factor (CF)}

The condition factor (CF) shows the physiological wellbeing of the prawn. The condition factor (CF) was determined for samples taken in each month and sex separately. The condition factor for M. nipponense was calculated using the following equation (Enin, 1994): 
$\mathrm{CF}=100 * \mathrm{~W} / \mathrm{L}^{3}$

Where: $\mathrm{CF}=$ Condition factor; $\mathrm{L}=$ Length $(\mathrm{cm}) \mathrm{W}=$ Weight $(\mathrm{g})$

\section{Sex ratio}

The sex of the specimens was determined by examining the presence or absence of sexual appendages in the second abdominal legs. The male to female ratio was based on the frequency of prawns caught during the sampling period. The sex ratio of male to female individuals was assessed. The sex ratio was estimated as (Pena-Mendoza $\boldsymbol{e t}$ al., 2015):

$M / F$, where $M=$ Number of males, $F=$ Number of females

\section{Statistical Analysis}

The Shapiro-Wilk test was used to determine the normality of the data. Analysis of variance (ANOVA), with the Tukey Post Hoc Test, was used to indicate whether the differences obtained were significant or not. A non-parametric test (Chi-square test) was employed to assess the significant difference of sexes every month. All statistical analyses were done using SPSS (Version 16), while figures were produced using Excel (Version 2019).

\section{RESULTS}

\section{Length-Frequency distribution}

The mean weight and length of prawns were $1.65 \pm 0.03 \mathrm{~g}$ and $4.5 \pm 0.1 \mathrm{~cm}$, respectively. There was a significant difference in total length between samples collected in a different season ( $\mathrm{P}<0.05)$. However, there was no significant difference in April, May, June, October, or November (Table 1). Analysis of variance of body weight showed significant differences in a different season $(\mathrm{P}<0.05)$. However, there was no significant difference in spring or autumn $(\mathrm{P}>0.05)$ (Table 1).

\section{Sex ratio}

The majority of prawns were sexually mature, and the total male: female ratio was 1:1.95. There was a significant difference in the male and female ratio $\left(\chi^{2}=69.21\right.$, $\mathrm{P}<0.05)$; therefore, sexual frequency in this species' population was not equal. However, the sex ratio was significantly different in some months. The highest difference between the number of males and females was in September (1:2.89), while the lowest was in December (1:1.06) (Table 1). 
Table1. Biological data of examined specimens and regression coefficient (b) and correlation coefficient $\left(\mathrm{R}^{2}\right)$ of the length-weight relationship of M. nipponense in the Siah Darvishan river

\begin{tabular}{lcllll}
\hline Month & M/F ratio & Weight $(\mathbf{g}) \pm \mathbf{S E}$ & Length $(\mathbf{c m}) \pm \mathbf{S E}$ & $\mathbf{R}^{2}$ & $\mathbf{b}$ \\
\hline January & $1: 1.68$ & $0.38 \pm 0.23^{\mathrm{a}}$ & $3.41 \pm 0.13^{\mathrm{a}}$ & 0.959 & 3.08 \\
February & $1: 1.71$ & $0.45 \pm 0.20^{\mathrm{a}}$ & $3.59 \pm 0.10^{\mathrm{a}}$ & 0.936 & 3.09 \\
March & $1: 1.89$ & $0.41 \pm 0.22^{\mathrm{a}}$ & $2.89 \pm 0.12^{\mathrm{a}}$ & 0.958 & 3.09 \\
April & $1: 2.25^{*}$ & $1.50 \pm 0.08^{\mathrm{b}}$ & $4.61 \pm 0.06^{\mathrm{b}}$ & 0.919 & 3.18 \\
May & $1: 2.48^{*}$ & $1.62 \pm 0.18^{\mathrm{b}}$ & $4.81 \pm 0.05^{\mathrm{b}}$ & 0.878 & 3.15 \\
June & $1: 2.57^{*}$ & $2.22 \pm 0.11^{\mathrm{c}}$ & $4.45 \pm 0.09^{\mathrm{b}}$ & 0.948 & 3.28 \\
July & $1: 2.01^{*}$ & $2.90 \pm 0.16^{\mathrm{c}}$ & $5.98 \pm 0.11^{\mathrm{c}}$ & 0.921 & 3.09 \\
August & $1: 2.23^{*}$ & $2.82 \pm 0.20^{\mathrm{c}}$ & $5.84 \pm 0.09^{\mathrm{c}}$ & 0.956 & 3.08 \\
September & $1: 2.89^{*}$ & $2.49 \pm 0.16^{\mathrm{c}}$ & $5.79 \pm 0.08^{\mathrm{c}}$ & 0.942 & 3.22 \\
October & $1: 1.57$ & $1.72 \pm 0.20^{\mathrm{b}}$ & $4.84 \pm 0.11^{\mathrm{bd}}$ & 0.945 & 3.32 \\
November & $1: 1.48$ & $1.55 \pm 0.21^{\mathrm{b}}$ & $4.64 \pm 0.10^{\mathrm{bd}}$ & 0.963 & 3.08 \\
December & $1: 1.06$ & $1.49 \pm 0.18^{\mathrm{b}}$ & $4.15 \pm 0.8^{\mathrm{d}}$ & 0.952 & 3.09 \\
\hline
\end{tabular}

\section{Length-weight relationship}

Plots of the length-weight relationship (LWR) M. nipponense from the Siah Darvishan river are shown in Figure (2). A robust positive coefficient of determination was observed between the prawn length and weight in M. nipponense $\left(\mathrm{r}^{2}=0.96\right)$ in November, and in weak one $\left(\mathrm{r}^{2}=0.87\right)$ in May. The regression coefficient (b) ranged from January (3.08) to October (3.32). Comparison of allometric growth rates (b-values) of prawns using t-test showed significant differences $(\mathrm{P}<0.05)$ indicating a positive allometry growth of $M$. nipponense from the Siah Darvishan river. The regression correlation and coefficient factors are provided in Table (1). 

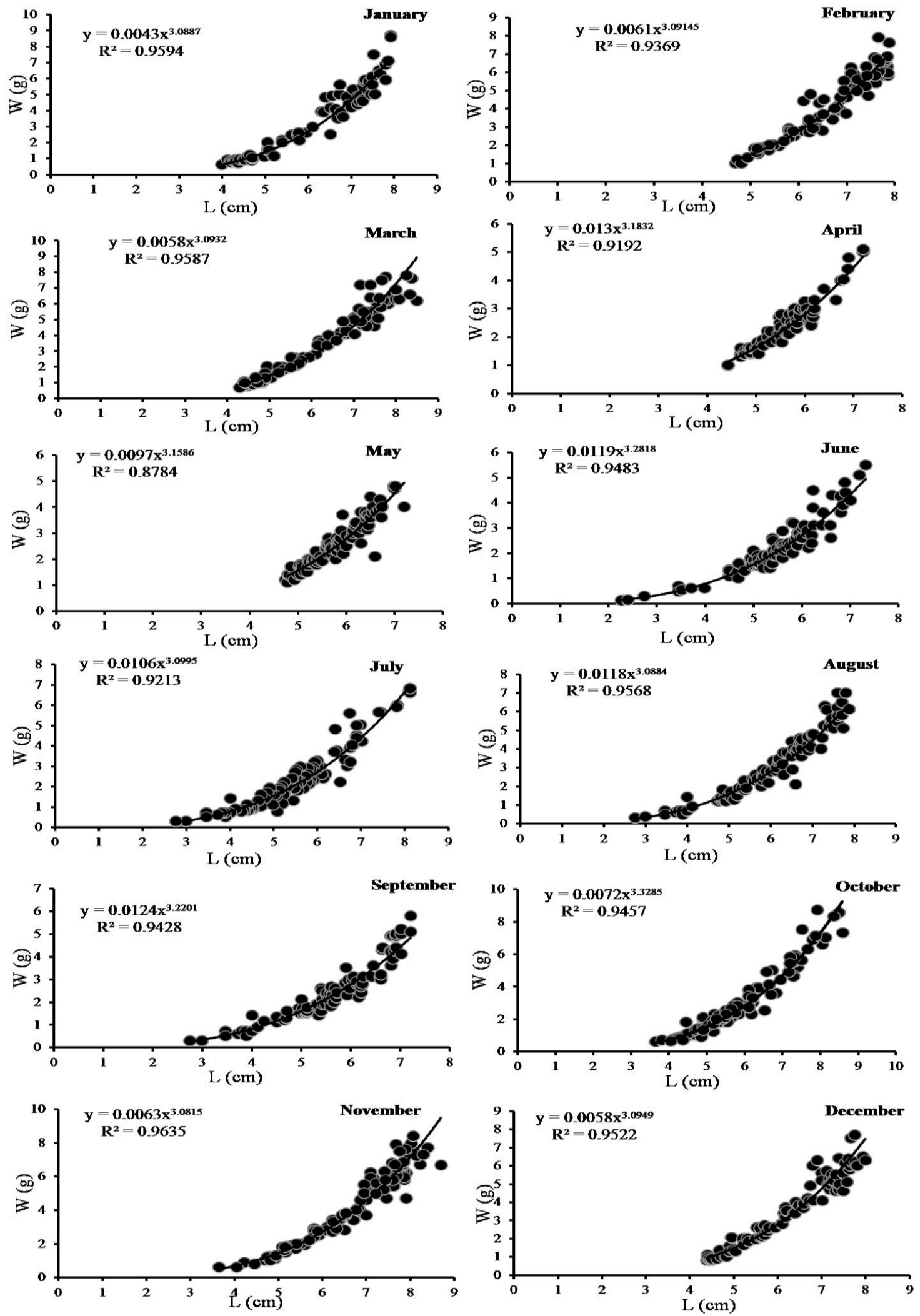

Figure 2. Length-weight relationship in M. nipponense from Siah Darvishan river 


\section{Condition Factor}

There were temporal variations in the condition factors of both sexes of the examined prawns (Figure 3). The condition factor of $M$. nipponense for males ranged from 0.78 in December to 1.3 in July, whereas for females, value recorded was 0.82 in April and 1.34 in September (Figure3). The condition factor of male and female differed significantly $(\mathrm{P}<0.05)$. However, there was no significant difference in April, June, July, or August $(\mathrm{P}>0.05)$.

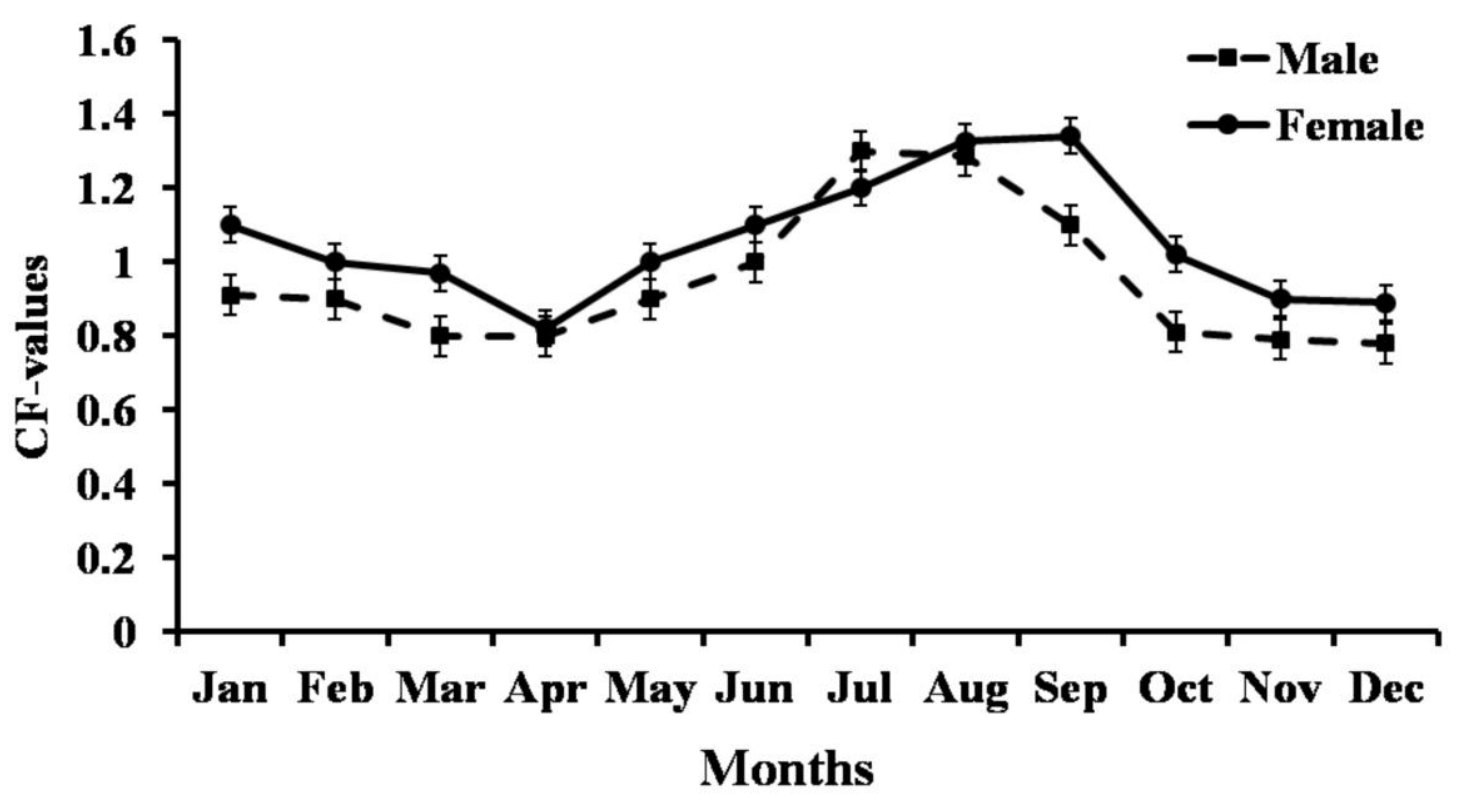

Figure 3. Condition factor for both male and female in M. nipponense from Siah Darvishan river.

\section{DISCUSSION}

Analysis of the length-weight relationship (LWR) of $M$. nipponense samples revealed a highly significant correlation between the total length and weight. During a year of observation, the $\mathrm{b}$ values showed that $M$. nippnense followed a positive allometric growth pattern, which coincides with the results of New et al. (2010) and Andem et al. (2013) concerning M. macrobrachion, and Lawal-Are et al. (2012) with respect to $P$. notialis. The slight variation in the values of $b$ and $r$ is understandable because the length-weight relationship of a species could vary according to various local factors such as salinity, temperature and fish health, sex, stage of maturity, length range of the species, food, and season (Zhang et al., 2014). Positive allometric growth patterns implied that the prawns became relatively stouter and deep-bodied as they increased in length, in particular (Moslen \& Miebaka, 2018). The correlation coefficient observed in this study $\left(r^{2}=0.87-0.96\right)$ showed a strong 
association between length and weight; the high value of the determination coefficient $\mathrm{r}^{2}$ indicated that the model applied for analysis fits the data.

The condition factor was calculated to assess the wellbeing of M.nipponense from the Siah Darvishan river. The condition factor was significantly different between males and females. Similar results were presented by Dineshbabu (2006), who compared condition factors of male and female of Metapenaeus Monoceros (a species of prawn in the family Penaeidae), Bhidiya. Values obtained for condition factor showed that both sexes of M.nipponense were in good condition. A particular seasonal trend was observed; the best condition factor for males (1.3 in July) and females (1.34 in September) was noticed during summer. There was no significant difference between male and female in April, Jun, July, or August because they reproduce in these months of the year, additionally, female during reproduction does not have feeding (New et al., 2010). Similar results were presented in the study of Andem et al. (2013), who reported that condition factors are significantly different in males and females of $M$. macrobrachion from the great Kwa River. In this essence, they attributed these differences to the feeding regime, time of the year, the higher weight of female gonad, organisms used, feeding behavior, biological factors, and responses to environmental perturbations. In addition, Namin et al. (2014) found CF values of 0.89-1.90 for M.nipponense.

\section{CONCLUSION}

In conclusion, $M$. nipponense follows an allometric growth pattern in the Siah Darvishan river. On the other hand, the high value of the correlation coefficient " $r$ " indicated a strong correlation between length and weight. In the end, the high value of the coefficient of determination $\mathrm{r}^{2}$ suggested that the model used for the analysis fits the data, hence confirms the fitness of the model. Furthermore, knowledge of lengthweight relationships and the condition factor of introduced or invaded species are essential to assess an appropriate management of alien and native species in an aquatic system.

\section{REFERENCES}

Abowei, J.F.N. (2010). The condition factor, length -weight relationship and abundance of Ilisha africana (Block, 1795) from Nkoro River Niger Delta, Nigeria. Adv. J. Food Sci. Technol, 2(1): 6-11.

Abowei, J.F.N.; Tawari, C.; Cdeekae, S.N. and Amakiri, N.E. (2008). A study of the length -weight relationship and condition factor of Pseudotolithus elangatus 
(Browdich, 1825) from Bonny Estuary, Niger Delta, Nigeria. Int. J. Trop. Agr. Food. Sys, 2(3-4): 249-254.

Andem, A. B.; Idung, J. U.; George, E. and Ubong G.U. (2013). Length-weight relationship and Fulton's Condition Factor of brackish river prawn (Macrobrachium macrobrachion, Herklots, 1851) from Great Kwa River, Obufa Esuk beach, Cross River state, Nigeria. European Journal of Experimental Biology, 3(3):722-730.

\section{Bacheler, N.M.; Schobernd, C.M.; Schobernd, Z.H.; Mitchell, W.A.; Berrane, D.J.;} Kellison, G.T. and Reichert, M.J.M. (2013). Comparison of trap and underwater video gears for indexing reef fish resence and abundance in the southeast United State. Fisheries Research, 143: 81-88.

Coad, B.W. (2016). Review of the pikes of Iran (Family Esocidae). Iranian Society of Ichthyology, 3(3): 161-180.

Cruz, Y.M. and Olatunbosun, O. (2013). Comparative Study on the efficiency of three different types of crab pot in Iceland fishing ground. UNU-Fisheries Training Program, 4:1-25.

De Grave, S. and Ghane, A. (2006). The Establishment of the Oriental River Prawn, Macrobrachium nipponense (de Haan), in Anzali Lagoon. Iran. Aquatic Invasions, 4: 204-208.

De Haan,W. (1833-1850). Crustacea. In: von Siebold PF Fauna Japonica sive description animalium, quae in itenere per Japoniam, jussu et auspiciis superiorum, qui summum in India Batava imperium tenent, suscepto, annis 1823-1830 collegit, notis, observationibus et admumbrationibus illustravit. Lugduni-Batavorum, i-xvii, ix-xvi, 1-243, [244], I-xxxi, Plates A-J, L-Q, 1-55.

Dineshbabu, A.P. (2006). Length-weight relationship and growth of the speckled shrimp Metapenaeus monoceros (Fabricius) off Saurashtra. Journal of Marine Biolology Ass. India, 48 (2): 180 - 184.

Enin, U.I. (1994). Length- weight parameters and condition factor of two West African Prawns. Rev. Hydrobiol. Trop, 27(2): 121-127.

Jones, R.E.; Petrell, R.J. and Pauly, D. (1999). Using modified length-weight relationships to assess the condition of fish. Aquacultural Engineering, 20: 261-276. 
Khanipour, A.A.; Noori, A.; Amini, M. and Kamrani, E. (2020). Length-weight relationship and Fulton's condition factor of Macrobrachium nipponense (De Haan, 1849) in Anzali lagoon of Iran. Iranian Journal of Fisheries Sciences, 19(1): 496-500.

Lawal-Are A.O. and Akinjogunla V. F. (2012). Length- Weight Relationships and Condition Factor in Lagos Lagoon, South West, Nigeria. Science and Technology, 2(3): 32-40.

Major, R.N.; Taylor, D.I.; Conner, S. and Conner G. (2016). Factors affecting bycatch in a developing New Zealand scampi potting fishery. Fisheries Research, 10:55-64.

Moslen, M. and Miebaka, C.A. (2018). Condition factor and length-weight relationship of two estuarine shell fish (Callinectes Sp and Penaeus sp) from the Niger Delta, Nigeria. International Journal of Fisheries and Aquatic Studies, 6(1): 188-194

Namin, J.I.; Nami, E. and Heidary, S. (2014). Length-Weight Relationship and Fulton's Condition Factor of Macrobrachium nipponense (Dehaan, 1849) in southern coasts of the Caspian Sea-Iran. International journal of Advanced Biological and Biomedical Research, 2(5):1650-1656.

New, M.B.; Valenti, W.C.; Tidwell, J.H.; DAbramo, L.R. and Kutty, M.N. (2010). Fresh water prawn's biology and farming. Wiley-Blackwell publishing, 542 PP.

Pauly, D. (1983). Some simple methods for the assessment of tropical fish stocks. FAO fish tech Rap, 234.52.

Peña-Mendoza, B.; Gómez-Márquez, J.L.; Salgado-Ugarte, I.H. and RamírezNoguera, D. (2015). Reproductive biology of Oreochromis niloticus (Perciformes: Cichlidae) at Emiliano Zapata dam, Morelos, Mexico. Rev. Biol. Trop, 53 (3-4): 515522.

Sparre, P.; Ursin, E. and S.C. Venema. (1989). Introduction to tropical fish stock assessment. Part 1. Manual FAO Fisheries Technical. FAO Rome, pp: 337.

Wakefield C.B. (2015). Length selectivity of commercial fish traps assessed from in situ comparisons with stereo-video: Is there evidence of sampling bias. Fisheries Research, 161: 145-155.

Zhang, Sh.; Jiang, S.; Xiong, Y.; Fu, H.; Sun, Sh.; Qiao, H.; Zhang, W.; Jiang, F.; Jin, Sh. and Gong, Y. (2014). Six chitinases from oriental river prawn Macrobrachium nipponense: cDNA characterization, classification and mRNA expression during post-embryonic development and moulting cycle. Comparative Biochemistry and Physiology, Part B, 167: 30-40. 